\title{
Discrimination in death? Unmarried couples and bereavement benefits
}

Simpson, M. (2019). Discrimination in death? Unmarried couples and bereavement benefits. Journal of Social Welfare and Family Law, 41(2), 218-221. https://doi.org/10.1080/09649069.2019.1590907

Link to publication record in Ulster University Research Portal

\section{Published in:}

Journal of Social Welfare and Family Law

Publication Status:

Published (in print/issue): 22/03/2019

DOI:

10.1080/09649069.2019.1590907

\section{Document Version}

Author Accepted version

\section{General rights}

Copyright for the publications made accessible via Ulster University's Research Portal is retained by the author(s) and / or other copyright owners and it is a condition of accessing these publications that users recognise and abide by the legal requirements associated with these rights.

\section{Take down policy}

The Research Portal is Ulster University's institutional repository that provides access to Ulster's research outputs. Every effort has been made to ensure that content in the Research Portal does not infringe any person's rights, or applicable UK laws. If you discover content in the Research Portal that you believe breaches copyright or violates any law, please contact pure-support@ulster.ac.uk. 
This is an the author's original version (submitted version) of an case comment published by Taylor \& Francis in the Journal of Social Welfare and Family Law. The version of record is: M Simpson, 'Discrimination in death? Unmarried couples and bereavement benefits' (2019) 41(2) JSWFL 218 <https://doi.org/10.1080/09649069.2019.1590907>

\section{Case analysis: In re McLaughlin [2018] UKSC 48 Mark Simpson}

\section{Submission to Journal of Social Welfare and Family Law}

The UK Supreme Court has held the blanket exclusion of unmarried cohabitees from a bereavement benefit in Northern Ireland incompatible with the non-discrimination provision in article 14 of the European Convention on Human Rights, read with article 8 (the right to respect for private and family life). While Lady Hale delivered the leading judgment, Lord Mance most succinctly summarised the four-to-one decision:

"A policy in favour of marriage or civil partnership may constitute justification for differential treatment, when children are not involved. But it cannot do so in relation to a benefit targeted at the needs and wellbeing of children." ${ }^{1}$

Siobhan McLaughlin had lived with her partner for 23 years at the time of his death and the couple had four children. Although McLaughlin's partner had made the necessary national insurance contributions, her application for a bereavement payment and widowed parent's allowance failed because eligibility is restricted to surviving spouses or civil partners. A bereavement payment is a one-off payment on the death of a spouse or civil partner who has made the necessary national insurance contributions. A widowed parent's allowance continues for as long as the survivor receives child benefit in respect of any of the couple's children, and has not entered a new marriage, civil partnership or cohabiting relationship. ${ }^{2}$ Equivalent benefits exist in Great Britain, ${ }^{3}$ but in both jurisdictions are being replaced by the new bereavement support payment. ${ }^{4}$

Refusal of bereavement payment was upheld by the High Court. ${ }^{5}$ Denial of access on the basis of marital status represents discrimination in the enjoyment of a right protected by protocol 1 , article 1 (P1-1) ECHR, and possibly article 8. However, the legitimate aim of promoting and recognising the special status of marriage and civil partnership meant the restriction was not manifestly without reasonable foundation, so did not contravene article 14 . On the other hand, the main purpose of widowed parent's allowance was not recognition of the significance of marriage and civil partnership, but support with the cost of raising children. In this case, there could be no reasonable justification for the exclusion of surviving cohabitees. The eligibility criteria were contrary to article 14 ECHR, read with article 8.

The decision regarding widowed parent's allowance was overturned on appeal. Weatherup $L$ held that Treacy J had placed too much emphasis on the "birth status" of McLaughlin's children - who were not applicants - when the applicant's own marital status was the relevant consideration. ${ }^{6}$ The judgment refers to the clearly stated intention of the legislature and the executive that unmarried cohabitees are not among the intended beneficiaries of widowed parent's allowance. Evidently, the Court of Appeal felt Treacy J had been too ambitious in making inroads into the discretion of

\footnotetext{
${ }^{1}$ In re McLaughlin [2018] UKSC 48 at [52] (Lord Mance)

${ }^{2}$ Social Security Contributions and Benefits (Northern Ireland) Act 1992 c7 s36; s39A

${ }^{3}$ Social Security Contributions and Benefits Act 1992 c4 s36; s39A

${ }^{4}$ Pensions Act 2014 c19 s30; Pensions Act (Northern Ireland) 2015 c5 part 53(2)

${ }^{5}$ In the matter of an application by Siobhan McLaughlin for judicial review [2016] NIQB 11; see M Simpson, 'Case comment: In the matter of an application by Siobhan McLaughlin for judicial review' (2016) 23(2) Journal of Social Security Law 106

${ }^{6}$ Application by McLaughlin for judicial review [2016] NICA 53 at [61] (Weatherup LJ)
} 
This is an the author's original version (submitted version) of an case comment published by Taylor \& Francis in the Journal of Social Welfare and Family Law. The version of record is: M Simpson, 'Discrimination in death? Unmarried couples and bereavement benefits' (2019) 41(2) JSWFL 218 <https://doi.org/10.1080/09649069.2019.1590907>

Parliament and the Government in the realm of social and economic policy. This emphasis on "the importance of the nexus between the survivor and the deceased" as opposed to that between the children and the deceased is maintained in Lord Hodge's dissenting Supreme Court judgment. ${ }^{7}$

Lady Hale first states more decisively than Treacy J that benefits "intended to promote family life," such as widowed parent's allowance, are one of the ways in which "states... demonstrate their respect for family life," and therefore fall within the ambit of article 8 as well as P1-1 ECHR. ${ }^{8}$ Article 14 may be invoked if persons in analogous situations are treated differently by the statutory scheme. Treacy J held that, for the purposes of widowed parent's allowance (although not bereavement payment), the applicant's position was analogous to a surviving spouse or civil partner with children. Weatherup $L$, citing the ECtHR decision in Shackell, ${ }^{9}$ found that the positions of a surviving spouse or civil partner and a surviving cohabitee were not analogous. Lady Hale agreed with Treacy J that, for the purposes of widowed parent's allowance, "the relevant 'facet of the relationship' [between McLaughlin and her partner] was not their public commitment but the coraising of children. For that purpose marriage and cohabitation were analogous." ${ }^{10}$ The Shackell judgment could not be treated as authority for the principle that marriage, civil partnership and cohabitation are never analogous for the purposes of bereavement benefits: each benefit must be considered individually in light of its intended purpose. Lord Mance more bluntly states that UK courts should simply treat the ECtHR in Shackell as "wrong."11 Lord Hodge agrees that the majority view is in conflict with Shackell, but unlike Lord Mance is "not persuaded that this court has grounds for departing from this consistent line of authority of the European court."12 Lady Hale also rejects Weatherup L's contention that the birth status of the children is irrelevant to the application, noting that the ECtHR has found (in non-social security cases) that "because children of married and unmarried parents should not be treated differently, neither should the unmarried parents." ${ }^{13}$

Having established that the matter falls within the ambit of article 8 and concerns differential treatment of people in analogous circumstances on the basis of an 'other status' potentially protected by article $14,{ }^{14}$ the question becomes whether a "reasonable and objective justification" for the discrimination exists. ${ }^{15}$ Normally, this requires that the discrimination is a proportionate means of achieving a legitimate aim. In cases concerning social security benefits - a matter of social and economic policy - the usual test is whether the discrimination is manifestly without reasonable foundation. ${ }^{16}$ Lady Hale accepts that the promotion of marriage and civil partnership represents a legitimate aim, sometimes pursued by providing for one member of the couple to benefit from the other's national insurance contributions. However, in the context of widowed parent's allowance it was "manifestly" disproportionate to afford preferential treatment on the basis of marriage or civil partnership. This is on the basis that:

\footnotetext{
${ }^{7}$ In re McLaughlin [2018] UKSC 48 at [58] (Lord Hodge)

${ }^{8}$ In re McLaughlin [2018] UKSC 48 at [17] (Lady Hale); Petrovic v Austria [1998] 33 EHRR 14 at [28]

${ }^{9}$ Shackell v United Kingdom [2000]

${ }^{10}$ In re McLaughlin [2018] UKSC 48 at [26] (Lady Hale)

${ }^{11}$ In re McLaughlin [2018] UKSC 48 at [49] (Lord Mance)

12 In re McLaughlin [2018] UKSC 48 at [64] (Lord Hodge)

${ }^{13}$ In re McLaughlin [2018] UKSC 48 at [28] (Lady Hale); see Sahin v Germany [2003] 2 FLR 671

${ }^{14} \operatorname{Re} G$ [2009] AC 173

15 Yigit v Turkey [2010] 53 EHRR 25 at [67]

${ }^{16}$ Stec v United Kingdom [2006] 43 EHRR 47
} 
This is an the author's original version (submitted version) of an case comment published by Taylor \& Francis in the Journal of Social Welfare and Family Law. The version of record is: M Simpson, 'Discrimination in death? Unmarried couples and bereavement benefits' (2019) 41(2) JSWFL 218 <https://doi.org/10.1080/09649069.2019.1590907>

"The purpose of the allowance is to diminish the financial loss caused to families with children by the death of a parent. That loss is the same whether or not the parents are married to or in in a civil partnership with one another." ${ }^{17}$

Accordingly, it "is not a difficult conclusion to reach [that McLaughlin's] children should not suffer this disadvantage because their parents chose not to marry." ${ }^{18}$

The Supreme Court decision is significant for various reasons. Most directly, it concerns the future shape of bereavement benefits. Its exact impact is uncertain, as the application concerned a Northern Ireland benefit (albeit mirroring one in Great Britain) that is being phased out. As Lady Hale highlights, the declaration of incompatibility does not affect the validity of the legislation. Parliament or the Assembly may or may not choose to make amendments to secure compatibility. From Siobhan McLaughlin's point of view, the judgment confirms that she has no entitlement to benefit, as the declaration certifies that it is impossible for the social security authorities to interpret the rules so that the reference to a 'spouse' includes persons in her position.

Looking ahead, a judicial review of the ECHR compatibility of bereavement support allowance is all but inevitable. Lady Hale is careful to state that the McLaughlin judgment is not determinative of what position the court might take in such a case, but it is hard to imagine a similarly-composed Supreme Court, faced with a similar applicant, reaching a different decision. In Great Britain, this would mean a declaration of incompatibility in respect of the relevant statutory provisions. In Northern Ireland, unlike widowed parent's allowance, bereavement support payment is based on devolved legislation. Since the devolved legislatures lack competence to legislate contrary to the $\mathrm{ECHR},{ }^{19}$ the offending provisions would cease to have effect. The Assembly would have no choice but to amend the scheme, extending eligibility to surviving cohabitees in some (although not necessarily all) circumstances. ${ }^{20}$ In the current absence of a functioning Assembly, Parliament could choose to do so or could validate the current eligibility criteria through an Act of Parliament. Any intervention here would be controversial in light of Westminster's reluctance to legislate on reproductive rights in Northern Ireland, also subject to recent ECHR-based litigation. ${ }^{21}$

The case also speaks to wider issues around human rights protection in the UK. The myth that the authority of Parliament and the domestic courts is subordinate to the whims of "meddling Strasbourg judges" 22 is debunked. Lady Hale confirms that incompatibility with the ECHR does not affect the validity of the legislation. Further, despite Lady Hale's attempts to avoid explicitly disagreeing with the ECtHR, the two other judgments explicitly state that the Supreme Court's

\footnotetext{
17 In re McLaughlin [2018] UKSC 48 at [39] (Lady Hale)

18 In re McLaughlin [2018] UKSC 48 at [42] (Lady Hale)

${ }^{19}$ Northern Ireland Act 1998 c47 s6

${ }^{20}$ In re McLaughlin [2018] UKSC 48 at [43] (Lady Hale)

${ }^{21}$ Re Northern Ireland Human Rights Commission's Application for Judicial Review [2018] UKSC 27; see also S Wilson Stark, 'In Re Northern Ireland Human Rights Commission's Application for Judicial Review [2018] UKSC 27: a declaration in all but name?' (UK Constitutional Law Association, 12 June 2018) <https://ukconstitutionallaw.org/2018/06/12/shona-wilson-stark-in-re-northern-ireland-human-rightscommissions-application-for-judicial-review-2018-uksc-27-a-declaration-in-all-but-name/> accessed 10 October 2018

22 M Brown, 'MP raps meddling Strasbourg judges' (Daily Express, 21 April 2011)

<http://www.express.co.uk/news/uk/242000/MP-raps-meddling-Strasbourg-judges> accessed 10 October 2018
} 
This is an the author's original version (submitted version) of an case comment published by Taylor \& Francis in the Journal of Social Welfare and Family Law. The version of record is: M Simpson, 'Discrimination in death? Unmarried couples and bereavement benefits' (2019) 41(2) JSWFL 218 <https://doi.org/10.1080/09649069.2019.1590907>

position is irreconcilable with that Shackell. Not for the first time, the UK's highest court arguably goes further than Strasbourg in its protection of social rights. ${ }^{23}$

In doing so, Lady Hale is less explicit than her own previous judgment in SG in treating the state's obligation to treat the best interests of the child as a primary consideration (article 3(1) of the Convention on the Rights of the Child) as an integral part of the proportionality test in article 14/article 8 cases. ${ }^{24}$ However, not only article 3 , but articles 26 (the right to benefit from social security) and 2 (protection from discrimination in the enjoyment of the UNCRC rights) are said to have "reinforced" the position taken. There is even a rare reference to the International Covenant on Economic, Social and Cultural Rights, with the exclusion of children of unmarried parents from the advantages of widowed parent's allowance found to be "inconsistent" with the UK's obligations under article 10. ${ }^{25}$ Lady Hale has been one of the more ambitious Supreme Court justices in her use of treaties other than the ECHR in social rights cases; it will be interesting to see whether this approach becomes more widely accepted under her presidency.

\footnotetext{
${ }^{23} \mathrm{C}$ O'Cinneide, 'A modest proposal: destitution, state responsibility and the European Convention on Human Rights' (2008) (5) European Human Rights Law Review 583

${ }^{24} R$ (on the application of SG) $v$ Secretary of State for Work and Pensions [2015] UKSC 16; for discussion, see M Simpson, 'Social rights, child rights, discrimination and devolution: untangling the web' (2018) 40(1) Journal of Social Welfare and Family Law 3

${ }^{25}$ In re McLaughlin [2018] UKSC 48 at [40-41] (Lady Hale); there is no mention of the European Social Charter see M Simpson, 'Assessing the compliance of the UK social security system with the state's obligations under the European Social Charter' (2018) Human Rights Law Review (forthcoming)
} 